\title{
Interfacial Shear Stress with Pull-out Test at Zeolite Ceramic Matrix and SS316 Single Fiber
}

Sri Mulyo Bondan Respati ${ }^{1}$, Rudy Soenoko ${ }^{2}$ Yudy Surya Irawan ${ }^{2}$, Wahyono Suprapto ${ }^{2}$

\author{
${ }^{1}$ Wahid Hasyim University, Department of Mechanical Engineering, Faculty of Engineering, Semarang, 50236, Indonesia \\ e-mail: bondan@unwahas.ac.id \\ ${ }^{2}$ Brawijaya University, Department of Mechanical Engineering, Faculty of Engineering, Malang, 65145, Indonesia \\ e-mail: rudysoen@yahoo.com,yudysir@ub.ac.id,wahyos@ub.ac.id
}

\begin{abstract}
Natural zeolite ceramic is a material that can be used as bioceramics but it is fragile to crack. The weakness of ceramics can be overcome by making ceramic metals. The use of SS316 (stainless steel 316) fiber to strengthen the zeolite ceramic had been done in order to determine the interfacial relationship by using a fiber pull-out test. The content of SS316 fiber in the zeolite ceramic matrix, before and after the sintering, had been examined by using atomic absorption spectrum tests. The content of the elements in SS316 fiber, zeolite ceramic matrix and the interface layer was became clear by using EDX and XRD test. The results showed that the higher the sintering temperature, the higher the interfacial shear stress on pull-out test as well. However, at a temperature of $900^{\circ} \mathrm{C}$, the interfacial shear stress on pull-out test became low because of the $\mathrm{Fe}, \mathrm{FeNi}$, and $\mathrm{CrFe}$ was arisen in a thin layer of the interface. The optimum of the temperature sintering for making ceramic zeolite matrix and SS16 fibers was $850^{\circ} \mathrm{C}$ because of the highest interfacial shear stress.
\end{abstract}

Keywords: interfacials, pull-out, natural zeolite, SS316.

\section{INTRODUCTION}

Recently natural zeolite is used for biomaterials and become an object to be studied. Natural zeolite is a unique material which shaped in hollow framework $\mathrm{Si}_{2} \mathrm{O}_{4}$ crystals tetrahedral with shared oxygen. This crustal is also called as a hydro alumino-silicate which contain alkali and alkaline earth metals [1]. Because of the uniqueness, zeolites begin to be used in medical field because it has the compatibility with the human body [2]. This biocompatibility has been investigated by Bedi with stainless steel sprayed with zeolite where it resulted in more biocompatible materials [3]. In addition Zeolites can also be made of ceramic.

There have been several studies of zeolite ceramic, Histrov et al., had made an investigation of several porous ceramics at the temperatures of $800-1000^{\circ} \mathrm{C}$. The ceramics were tesed by using Bulgarian zeolites and it resulted in a porous ceramic except for the ceramic with $1000^{\circ} \mathrm{C}$ sintering [4]. Other researchers, San et al., had made some porous ceramics with a mixture of natural zeolite and quartz. The result, they had a ceramic with micro pores [5]. Zeolites can indeed be used for ceramics, but it has the fragilrity to crack and break [6]. To overcome this drawback, the ceramic can be enhanced by using a more ductile material as the reinforcement. The material that is safe for the strengthening and still had its bio-compatibility is the stainless steel (SS316) [7]. Before we go further, please noted thet zeolite ceramic and stainless steel are two different materials. Stainless steel had a positive expansion coefficient of $16 \times 10^{-6} /{ }^{\circ} \mathrm{C}$ [8] while the zeolite ceramic had a negative expansion coefficient of $-0.34 \times 10^{-6} /{ }^{\circ} \mathrm{C}$ [9]. Moreover, zeolite is classified into adsorption material which has no reaction to heavy metals [10]. The manufacture of the ceramic metals required a special technique that was the synchronization between the ceramic sintering temperature with the metal heating. The metal Heating with the high temperature will change the composition of its an element content. In accordance with the research of Guillaumet et al., [11] and Atanda et al., [12] stainless steel material if it is heated over $900^{\circ} \mathrm{C}$, it will turn into of chromium oxide. So that, by using natural zeolite to wrap the SS316, it is expected that the heating process will not to change the content of chromium in SS316 in regard that natural zeolite only adsorb heavy metals but not reacting with the metal. This synchronization can be seen by making a single fiber pull-out test on the ceramic metals. Cailleux et al. [13] conducted a single fiber pullout test using the stainless steel fiber as its fiber and the alumina ceramics as its matrix. The results were still 
in the form of the shear stress and the photo micro-specimens. Whereas in ceramic sintering involves heat at high temperatures. According to Bagby et al [14] during sintering there was a bond between the ceramic matrix with the metal fibers. The bonds that occur are mechanical bonding and chemical bonding.

The purpose of this study is to determine the effect of interfacial shear stress with single fiber pull-out test from the influence of sintering temperature. The matrix fiber interfacial properties are important for controlling the macro properties of composite materials. The fiber matrix interfacial properties are affected by the sintering temperature. The sintering temperature in this study is set at a temperature of $800-900^{\circ} \mathrm{C}$ in order to obtain such porous ceramics, these temperatures also include in the low temperature sintering the zeolite ceramic. While at a temperature of $800-900^{\circ} \mathrm{C}$ in the $\mathrm{SS} 216$ the diagram shows that it is on the austenite phase. Austenite phase is the phase that the elemental composition and microstructure of SS316 can be changed. The authenticity of this research is the occurrence of mechanical and chemical bonds between zeolite ceramic matrix with SS316 fibers.

\section{MATERIALS AND METHODS}

This study used natural zeolite materials with the chemical compositions of $66.9 \% \mathrm{SiO}_{2}, 11.43 \% \mathrm{Al}_{2} \mathrm{O}_{3}$, $4.59 \% \mathrm{Fe}_{2} \mathrm{O}_{3}, 0.18 \% \mathrm{TiO}, 2.40 \% \mathrm{CaO}, 1.44 \% \mathrm{MgO}, 1.95 \% \mathrm{~K}_{2} \mathrm{O}, 1.29 \% \mathrm{Na}_{2} \mathrm{O}, 9.66 \%$ others. The XRF test showed thet the zeolite contains, the contains of $4.8 \% \mathrm{Al}, 35.5 \% \mathrm{Si}, 6.22 \% \mathrm{~K}, 14.7 \% \mathrm{Ca}, 1,5 \% \mathrm{Ti}, 0.05 \% \mathrm{~V}$, $0.11 \% \mathrm{Cr}, 0.79 \% \mathrm{Mn}, 29.7 \% \mathrm{Fe}, 3.57 \% \mathrm{Ni}, 0.51 \% \mathrm{Cu}, 0.2 \% \mathrm{Zn}, 1.5 \% \mathrm{Sr}, 0.2 \mathrm{Ba}, 0.2 \% \mathrm{Eu}, 0.4 \% \mathrm{Re}$, And XRD Test on the zeolite was presented in Figure 1.

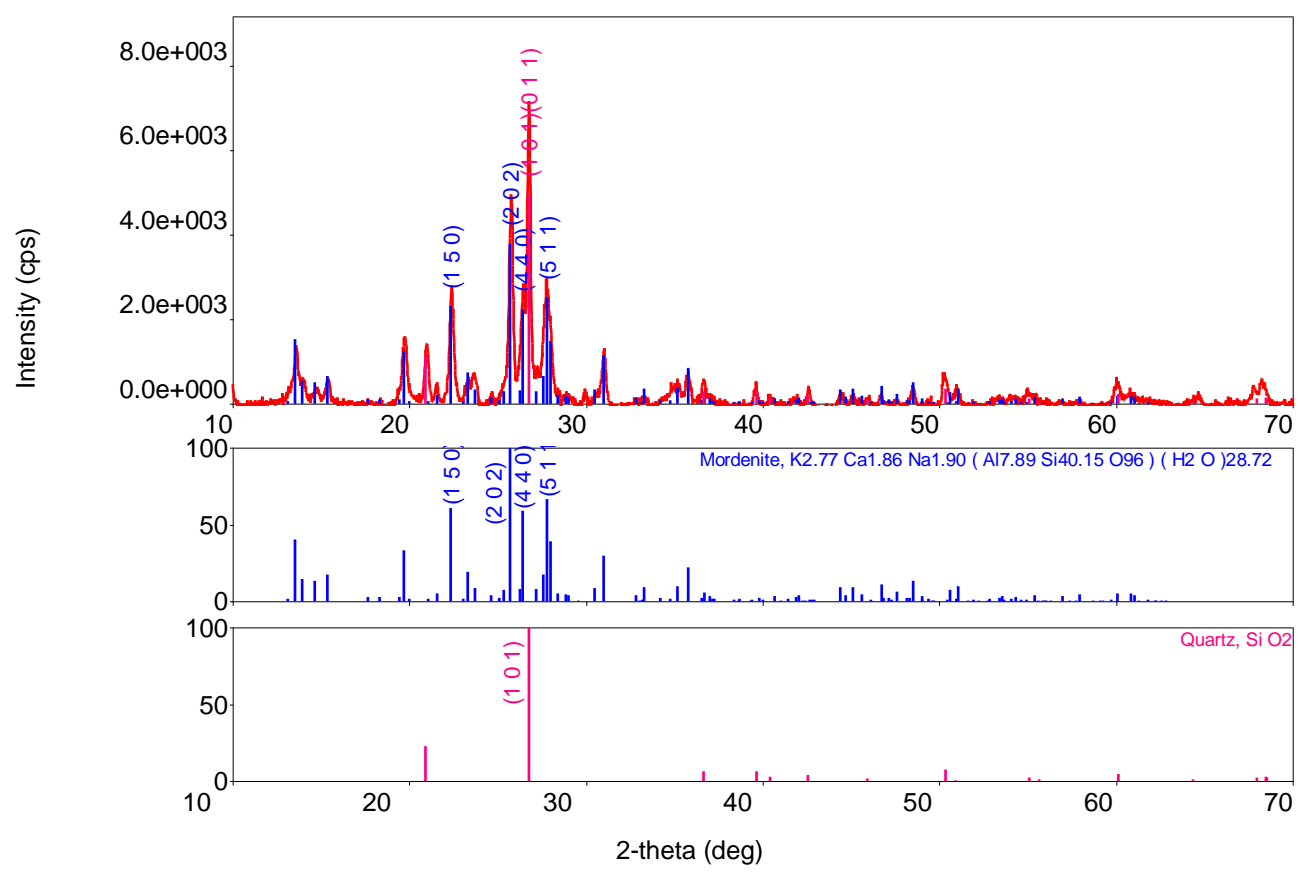

Figure 1: XRD of the nature zeolite.

The zeolite used was $88.7 \%$ mordenite type with the chemical formula $\mathrm{Na}_{8}\left(\mathrm{Al}_{8} \mathrm{Si}_{40} \mathrm{O}_{96}\right) \cdot 24 \mathrm{H}_{2} \mathrm{O}$ and $11.3 \%$ Quartz. Differences in the test presented are for the chemical test is a compound contained in the zeolite, the XRF is an element contained in the zeolite and the XRD to know the type of zeolite.

The other material was SS316 with chemical composition $72.5786 \% \mathrm{Fe}, 0.0036 \% \mathrm{~S}, 0.0014 \% \mathrm{Al}$, $0.0843 \% \mathrm{C}, 0.0313 \% \mathrm{Ni}, 0.0131 \% \mathrm{Nb}, 0.3416 \% \mathrm{Si}, 15.0250 \% \mathrm{Cr}, 0.046 \% \mathrm{~V}, 8.9687 \% \mathrm{Mn}, 0.0489 \% \mathrm{Mo}$, $0.0005 \% \mathrm{~W}, 0.0616 \% \mathrm{P}, 1.5097 \% \mathrm{Cu}, 0.0007 \% \mathrm{Ti}, 0.2144 \% \mathrm{~N}, 0.0012 \% \mathrm{~B}, 0.0218 \% \mathrm{Sb}, 0.0004 \%, 0.0041 \%$ $\mathrm{Mg}, 0.0049 \% \mathrm{Sn}$, and $0.0464 \%$ Co. Results from the EDX of the raw material SS316 was shown in Figure 2. 


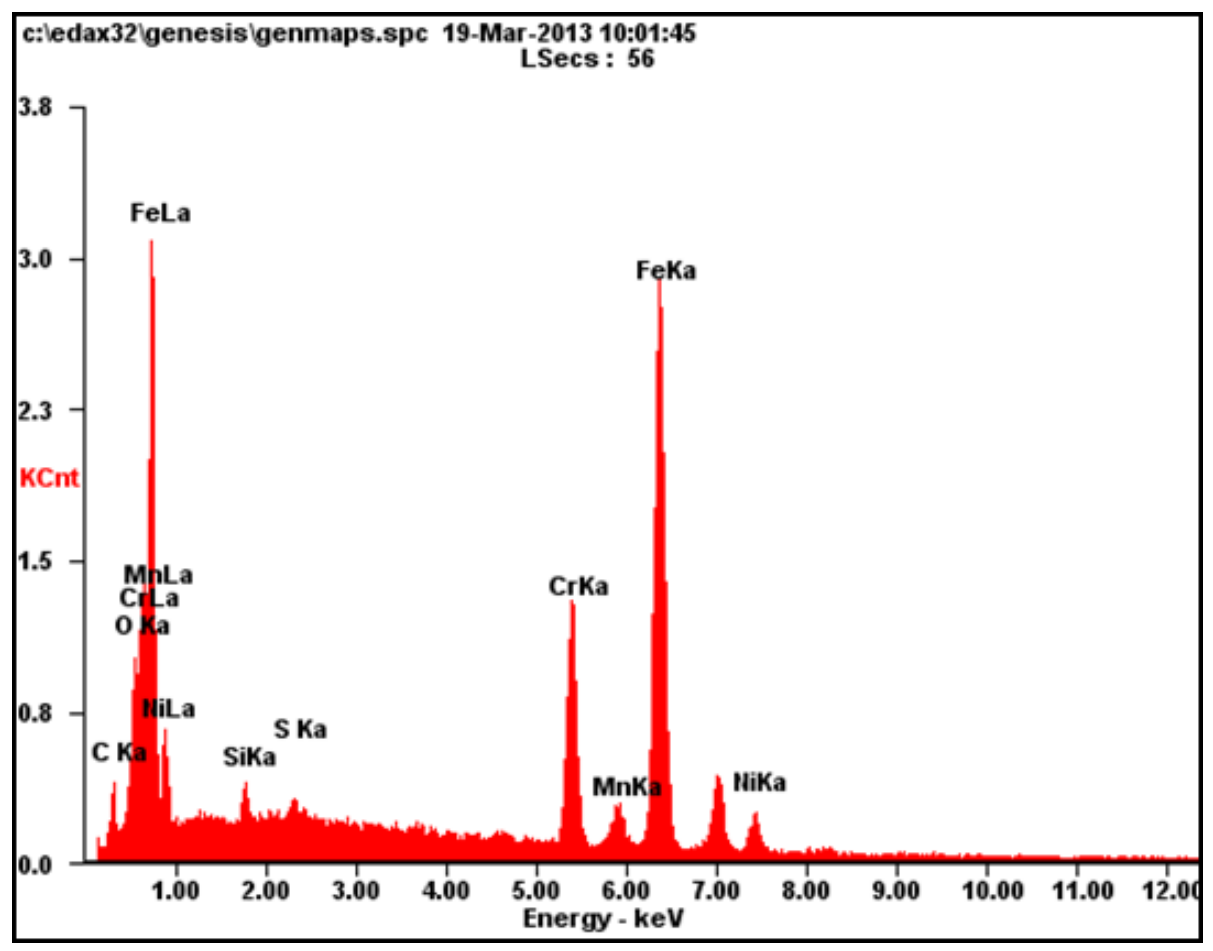

Figure 2: EDX diagram of the raw material SS316.

The elements present in the SS316 raw material in the EDX test were $07.56 \% \mathrm{C}, 0.35 \% \mathrm{Si}, 0.35 \% \mathrm{~S}$, $15.97 \% \mathrm{Cr}, 0.61 \% \mathrm{Mn}, 67.15 \% \mathrm{Fe}, 8.01 \% \mathrm{Ni}$. The element $\mathrm{C}$ on the EDX test results is high due to the etching effect.

This study also used three specimens; the single fiber pull-out test specimens, the single fiber specimens to take SS316 fiber for spectrum absorption and XRD test, and The interface test specimens. The size of the specimen is shown in Figure 3.
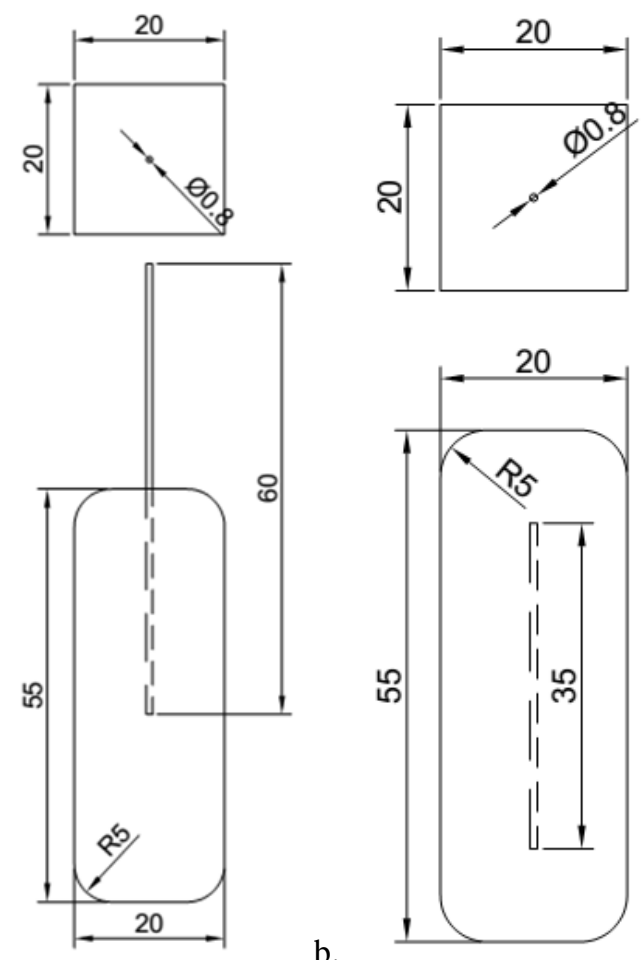

a.

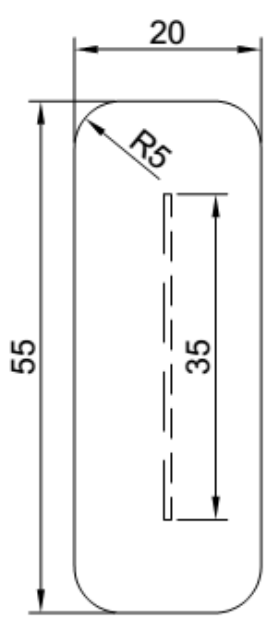

b.

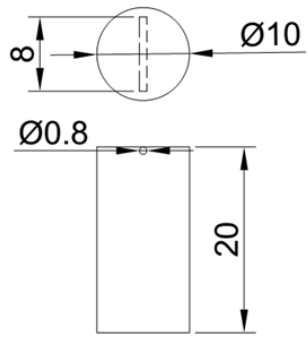

c.

Unit: $\mathrm{mm}$

Figure 3: The size of specimen a. Pull-out test specimen size. b. The single fiber specimen size c. The interface specimen size. 
This study used a single fiber for pull-out test. A single fiber pull-out test is used to determine the shear stress occurring on the surface between the zeolite ceramic matrix with stainless steel fibers. When the pull-out test only the fiber was drawn not the entire specimen, therefore the single fiber pull pull test does not take into account the ratio between the ceramic and the fiber. When pulling stainless steel fiber, ceramic was retained by a jig.

The shape of the pull-out test specimen was made to facilitate the making of the specimen and jig manufacture. A jig was made for SS316 fibers and ceramics matrix so that it would not be crushed by a jaw clamp tensile test equipment $[15,16]$. The preparation of the pull-out test setup is illustrated in Figure 4.

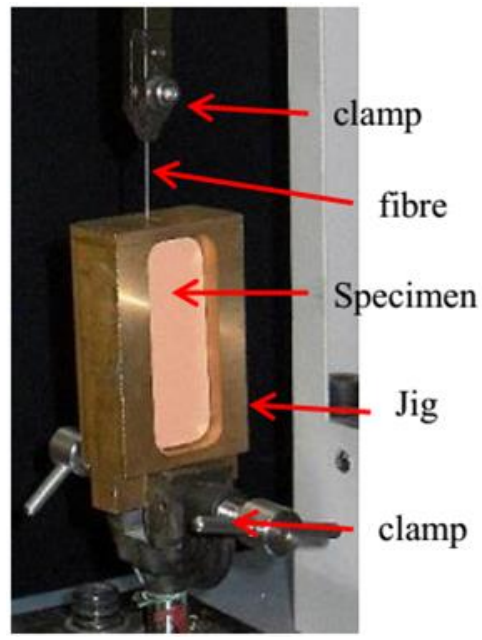

Figure 4: Test set up in pull-out test.

A specimen as in Figure 2b was to the find out if any the metal content in the SS316 was changed. The specimen has after sintered, the ceramic was destroyed to be taken of the SS316 fibers. The SS316 fibers obtained with the SS316 raw material were tested using an atomic absorption spectrum test. The thin layer attached to the SS316 was made powder. The thin layer powder was to be tested for XRD to reveal the content in a thin layer.

While had seeing the interface on the fiber and the ceramic were used specimens in Figure $2 \mathrm{c}$. Finished specimens rubbed at the top using sandpaper. Then the specimen is viewed with an optical microscope. The results of the micro-photograph were used to measure the distance of the interface. Several specimens were used the SEM and EDX test to confirm the interface layer content.

The making of the specimen was by using a natural zeolite with a grain size of less than 100 mesh sieve. Moreover, the compacting pressure on green part specimen was set in $25 \mathrm{MPa}$. The heating process was conducted by using electric furnace, sintering temperatures in $800^{\circ} \mathrm{C}, 850^{\circ} \mathrm{C}$ and $900^{\circ} \mathrm{C}$ with the holding time of 8 hours, heating rate of $5^{\circ} \mathrm{C}$ per minute and air cooling inside the furnace. The each sintering temperature variations were five samples of the specimens. The $800-900^{\circ} \mathrm{C}$ temperature variation was used because at a temperature sintering of $800^{\circ} \mathrm{C}$ the zeolite starts to melt and above a temperature sintering $900^{\circ} \mathrm{C}$, the SS316 content will change.

\section{RESULTS}

The shear stress was obtained by dividing the force by the area interfacial of fibers which were embedded. The results of the pull-out of shear stress test can be seen in Figure 5. 


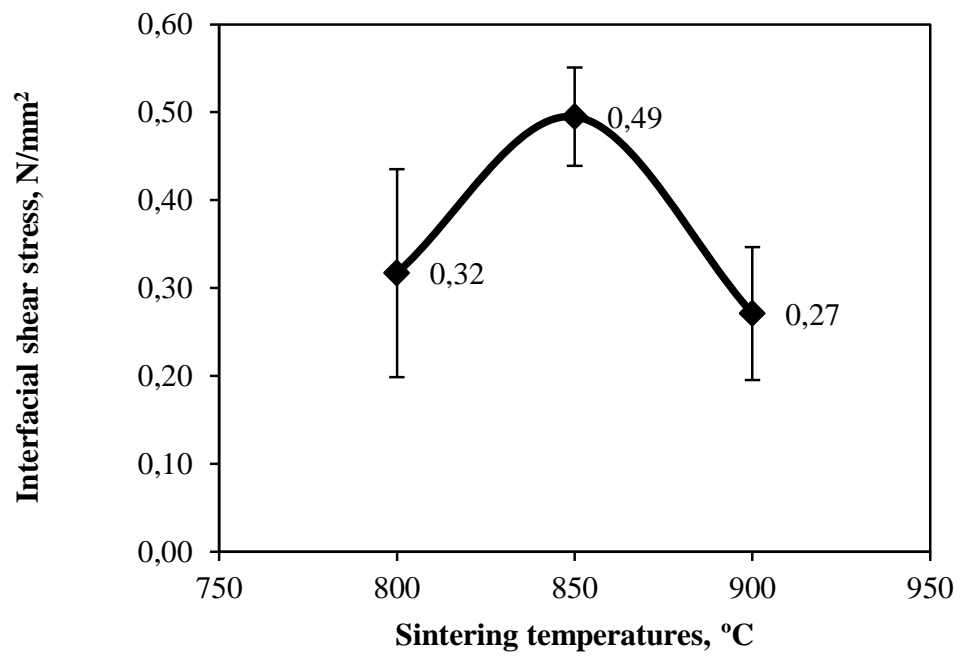

Figure 5: The Graph of sintering temperatures to pull-out of shear stress.

Figure 5 shows the graph of sintering temperature to the interfacial shear stress, shear stress is the highest at the sintering temperature of $850^{\circ} \mathrm{C}$ and it gets lower at the temperature of $900^{\circ} \mathrm{C}$. The changes in the interfacial shear stress are a sign that the ceramic shrinkage is affected the traction force to the SS316 fiber but the chemical reaction of elements at the temperature of $900^{\circ} \mathrm{C}$ is more influential. To determine the influence of sintering in stainless steel element, it is necessary to test the content of stainless steel further.

Atomic absorption spectrum test was used to know the contents of the elements in the stainless steel; SS316 fiber without treatment and SS316-zeolite ceramic specimen after sintering as in Figure 3b. The test results can be seen in Figure 6 and 7. Here Fe content diagram is being separated to clarify the differences which had occurred.
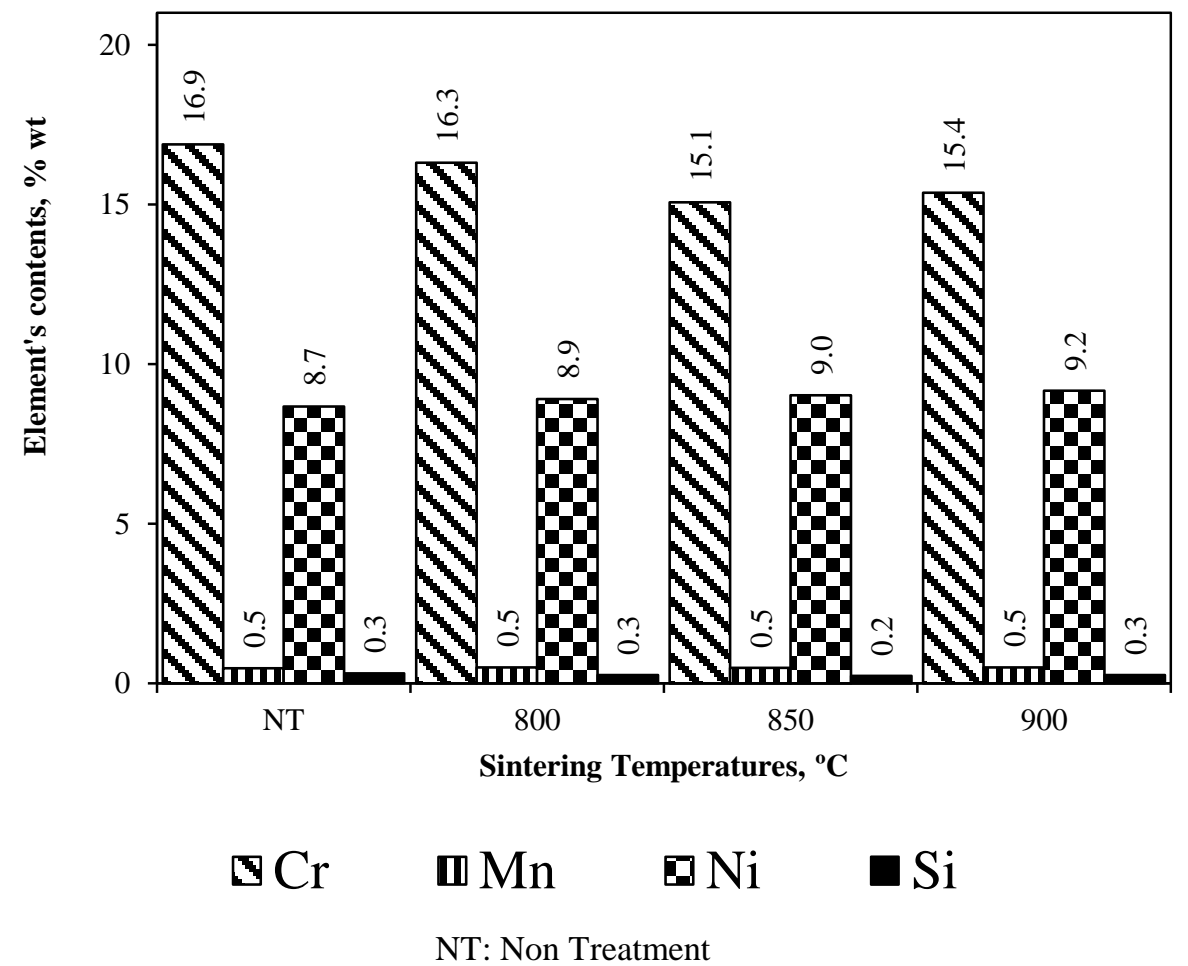

Figure 6: The element's contents without Fe in the SS316 fiber before and after the sintering inside the zeolite ceramic matrix. 
Figure 6 illustrates some of the metal content changes. The $\mathrm{Cr}$ content in the sintering temperature of $800^{\circ} \mathrm{C}$ is unchanged and at a temperature of $850^{\circ} \mathrm{C}$ and $900^{\circ} \mathrm{C}$ is down $1 \%$ wt. Non treatment in the graph defines the raw material SS316. While the content of Fe can be seen in this following Figure 7. Fe content was separated so that other elements can be read clearly.

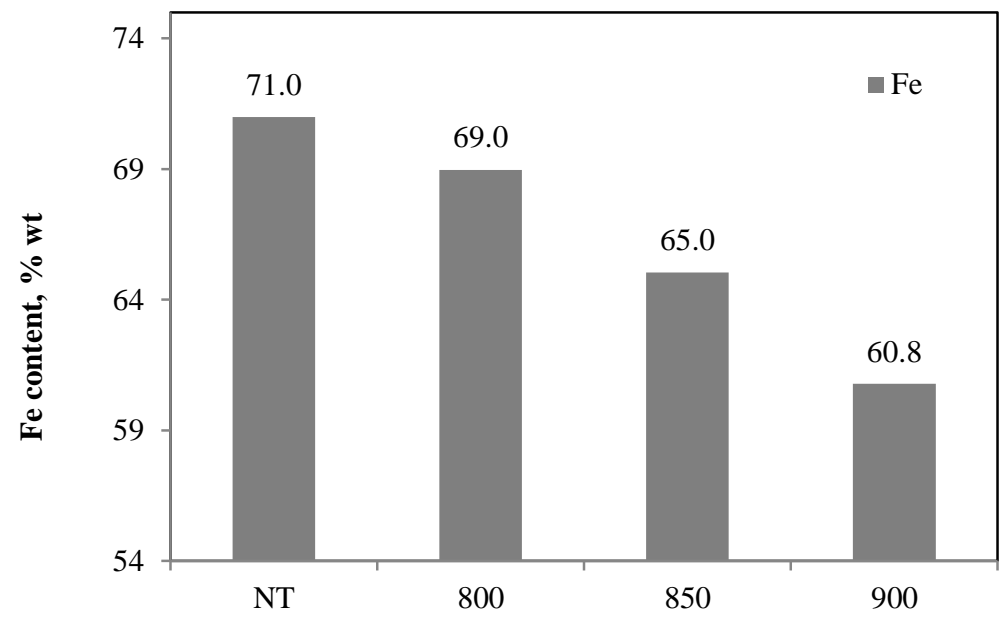

Sintering temperatures, ${ }^{\circ} \mathrm{C}$

NT: Non Treatment

Figure 7: Fe content in the SS316 fiber before and after the sintering inside the zeolite ceramic matrix.

Figure 7 indicates that the Fe content is reduced along with the increasing sintering temperature. It shows that the $\mathrm{Fe}$ content at the sintering temperature of $900^{\circ} \mathrm{C}$ is down up to $10 \%$ at $\mathrm{SS} 316$ without treatment. Further details of SS316 with a ceramic zeolite can be seen in EDX and SEM photos; EDX image can be seen in Figure 9. This following photo was taken from the specimen as show in Figure 5 which the surface was sanded so the fiber of SS316 can be seen clearly. The locations of the SS316 fiber, zeolites ceramic matrix and EDX area indicated by the yellow rectangle in Figure 8. The EDX extents which was exposed to SS316 is $76091.49 \mu \mathrm{m}^{2}$ while the area of the zeolite ceramic is $60534.25 \mu^{2}$ and the layers which were exposed is the spot indicated by "+" in Figure 8.

The SEM images show a collection of crust between ceramic zeolite matrix with SS316 fiber. The crust is believed to be the ferrite oxide which then is brought to be tested with EDX on three different locations In order to know more details. The results of EDX can be seen in Figure 9, 10 and 11.

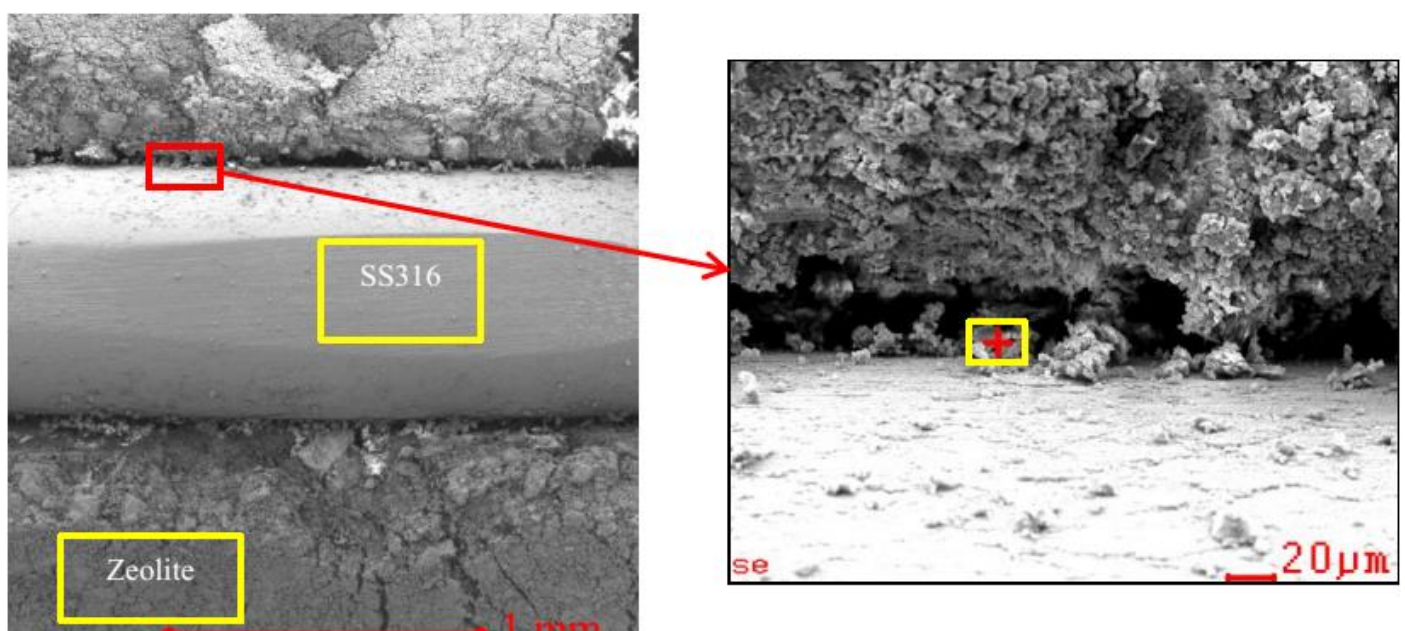

Figure 8: SEM photographs of SS316 fiber with zeolite ceramic matrix at sintering temperature of $900^{\circ} \mathrm{C}$. 


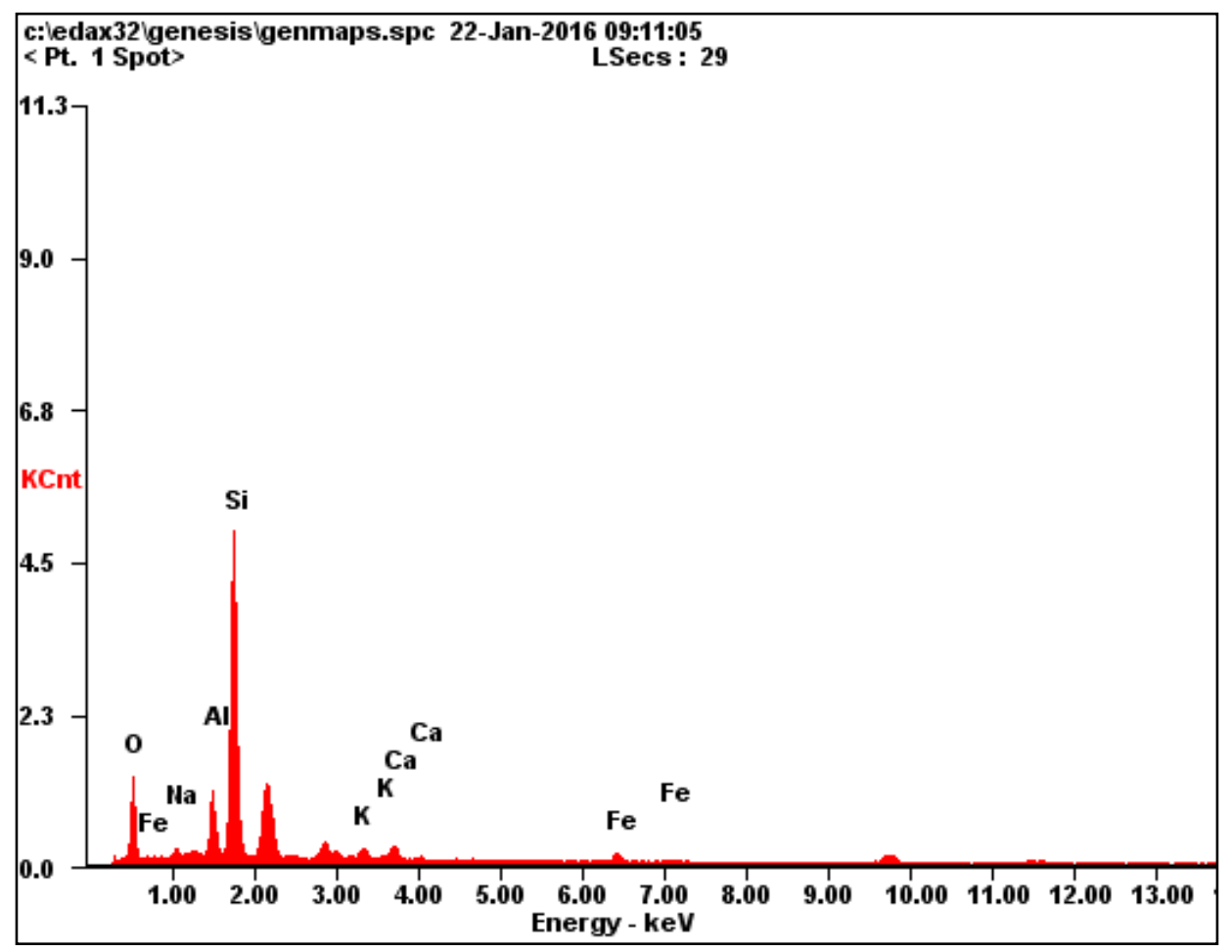

Figure 9: EDX diagram of zeolite ceramics on the sintering temperature of $900^{\circ} \mathrm{C}$.

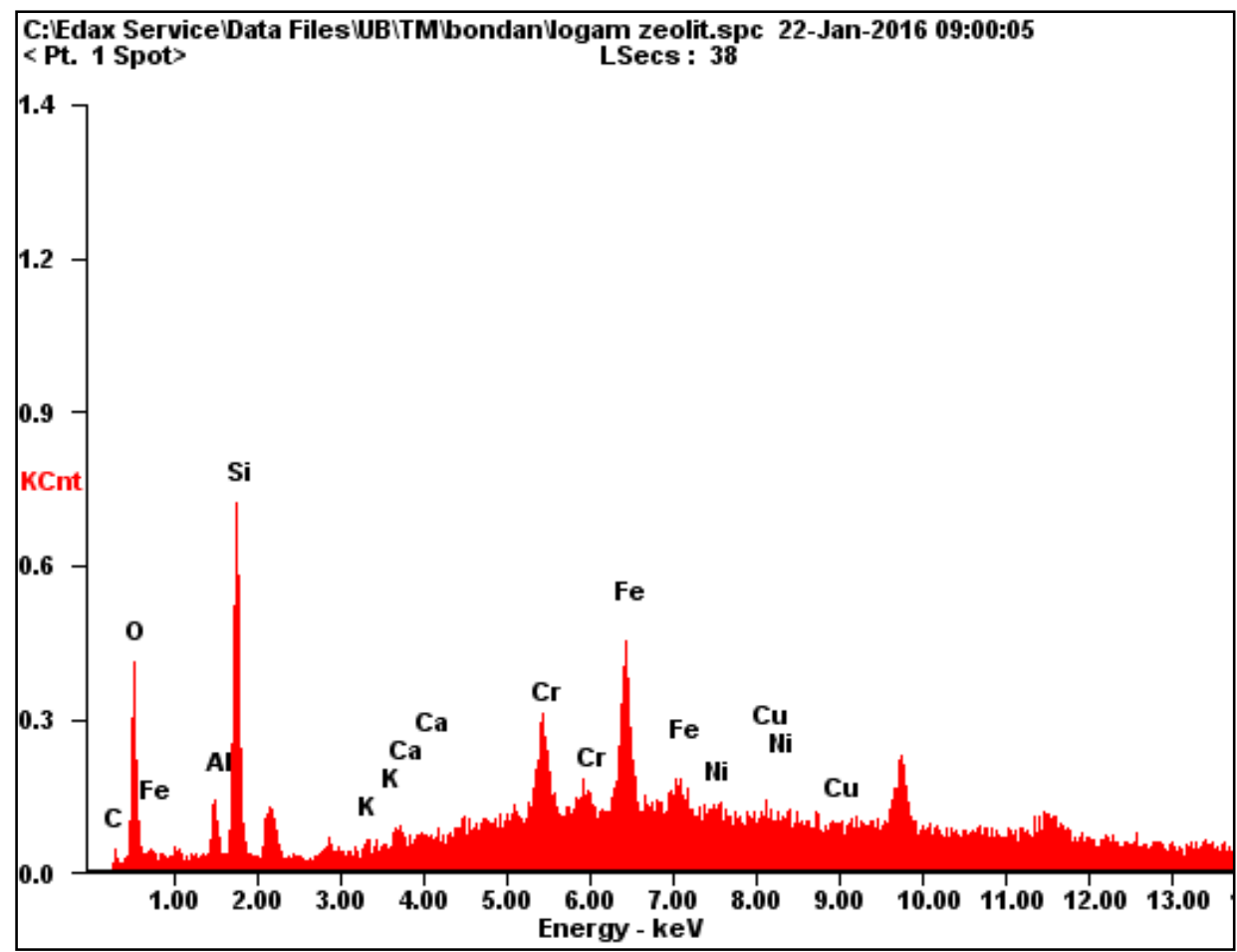

Figure 10: EDX diagram of particle between zeolite ceramics and ss 316 on the sintering temperature of $900^{\circ} \mathrm{C}$. 


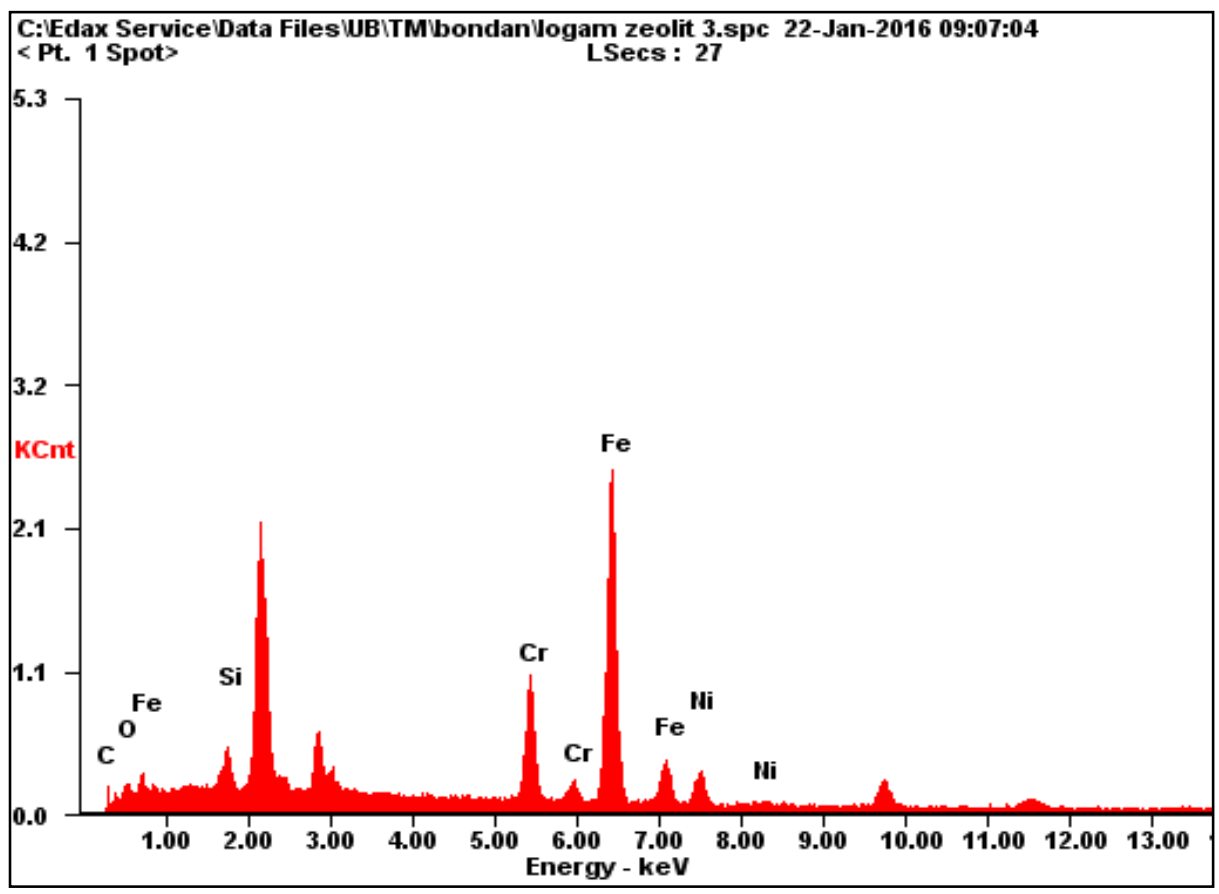

Figure 11: EDX diagram of SS316 on the sintering temperature of $900^{\circ} \mathrm{C}$.

The EDX results in Figure 10 show that the crust between SS316 with zeolite ceramic was a mix of both ingredients. Figure 11 illustrates the content in SS316 that are 5.96\% C, 2.27\% O, 2.7\% Si, $14.82 \% \mathrm{Cr}$, $64.49 \% \mathrm{Fe}, 9.77 \% \mathrm{Ni}$. When compared with raw material then the $\mathrm{Fe}$ and $\mathrm{Cr}$ elements are decreased on the SS316. To be more explicit the content in the thin crust, then the crust pulverized to the XRD test. The crust was taken at the sintering temperature of $900^{\circ} \mathrm{C}$ because at these temperatures the crust was seen the blackest and thickest (Figure 12a, c, and e). This crust powder is used to be tested by XRD test and the results can be seen in Figure 12.

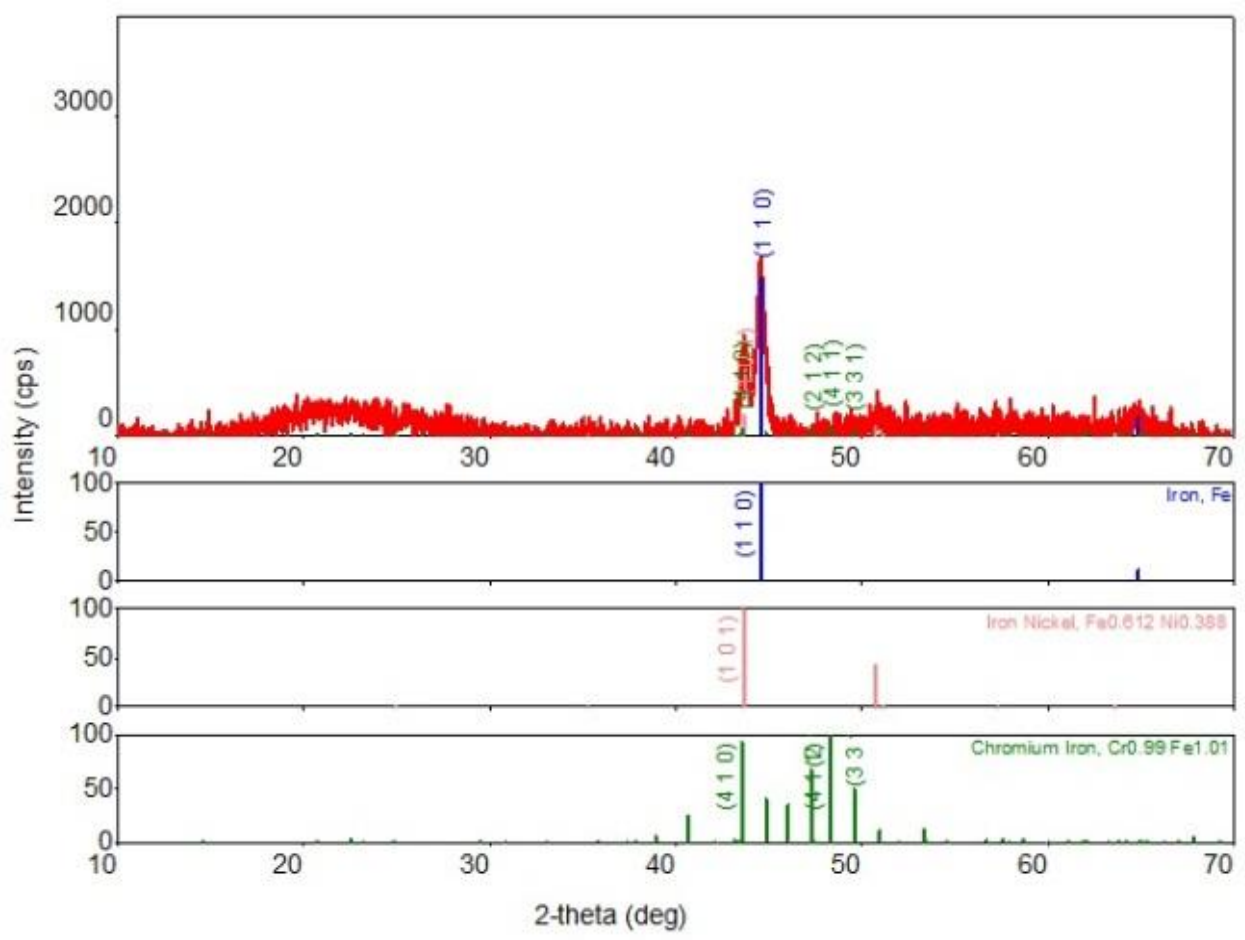

Figure 12: XRD crust layer test results between stainless steel with ceramic zeolite at a sintering temperature of $900^{\circ} \mathrm{C}$.

Figure 12 describes the results of a XRD layer between the stainless steel with a ceramic zeolite as for 
iron $(\mathrm{Fe})$, nickel iron $(\mathrm{FeNi})$, and chromium iron $(\mathrm{CrFe})$. To be more clear effect of thin layers, it can be seen in the macro image in the specimen after the pull-out test.

Fiber SS316 and a hole in zeolite ceramic matrix can be seen in the former specimens after a pull-out test. For more details, the former hole on zeolite ceramic matrix after pull-out test can be seen in Figure 13b, d, and e. Furthermore, fiber SS316 after it is being revoked can be seen in Figure 13a, c, and e.
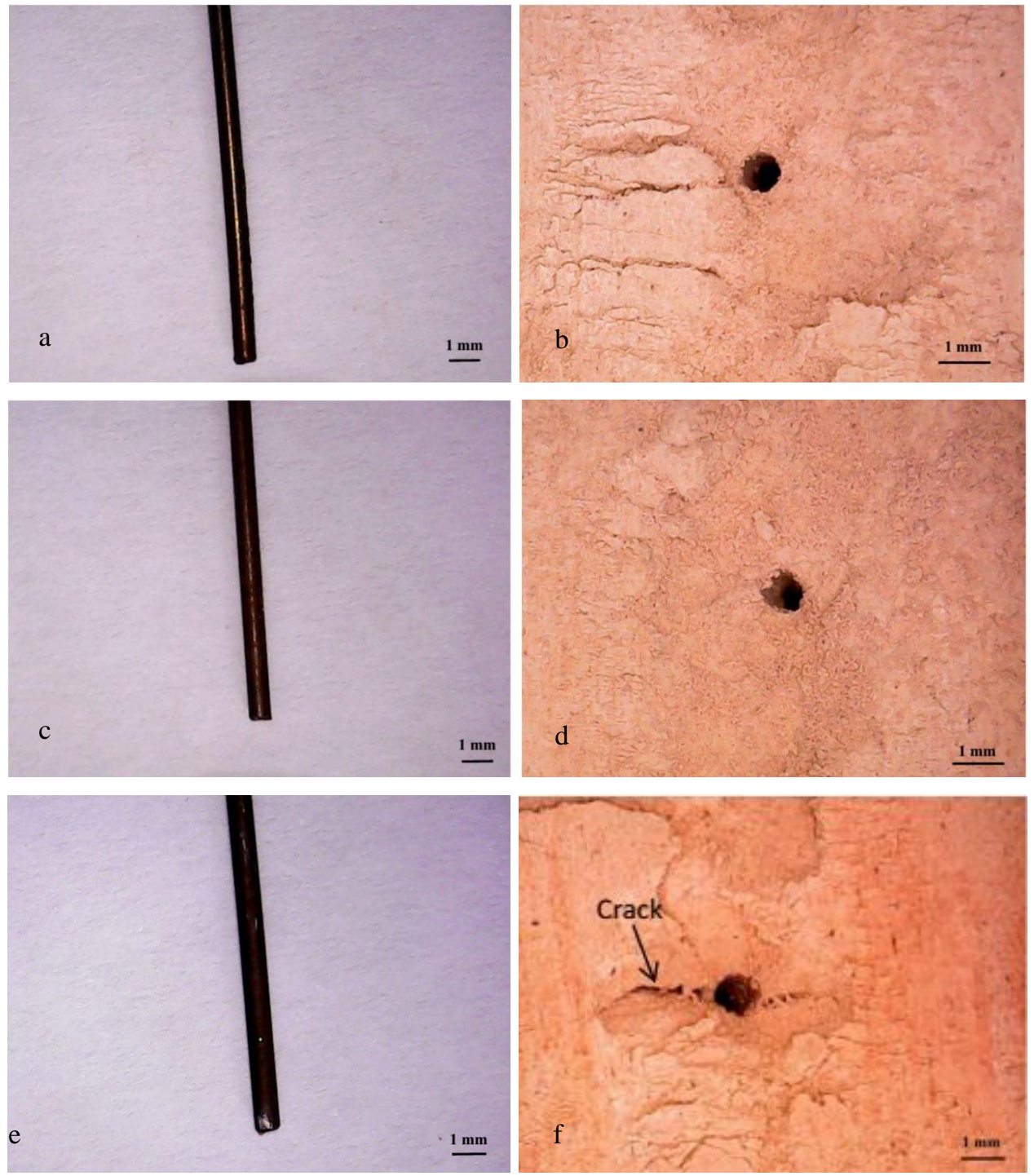

Figure 13: Specimens macro photo of SS316 fibers and zeolite ceramic matrixs after a pull-out test at a sintering temperatures of a and b. $800^{\circ} \mathrm{C}, \mathrm{c}$ and d. $850^{\circ} \mathrm{C}$, e and f. $900^{\circ} \mathrm{C}$

SS316 fiber is presented in Figure $13 \mathrm{a}$, c, and e. The SS316 fiber at the sintering temperature of $800^{\circ} \mathrm{C}$ is shinier than others. This indicated that the sintering temperature of $800^{\circ} \mathrm{C}$, cannot change the SS316 fiber. The diameter hole on zeolite ceramic matrix look bigger than the SS316 fiber diameter (Figure 13a and b). This hole explains that the shrinkage of the zeolite ceramic matrix cannot compensate the SS316 fiber which were exsiccate during the cooling process so that it is so obvious that there is a wide gap between the two materials. At a glance the sintering temperature of $850^{\circ} \mathrm{C}$ diameter hole in a zeolite ceramic matrix is equal to the diameter of SS316 fiber (Figure 13c and d). If it is carefully observed, then it had a very strong argument that the shear stress is also large. Meanwhile, at the sintering temperature of $900^{\circ} \mathrm{C}$, the SS316 fiber looks blackened where it refers that there is a change in fiber SS316 and the holes in the zeolite ceramic matrix had cracks although the diameter of the hole and the diameter of SS316 fibers are alike (Figure 13d and e). The specimen in Figure 3c is presented in order to see the gap between SS316 fiber with zeolite ceramic matrix, clearly it was photographed by using a microscope. The result of micro photograph of the interface distance measurement is shown in Figure 14. 

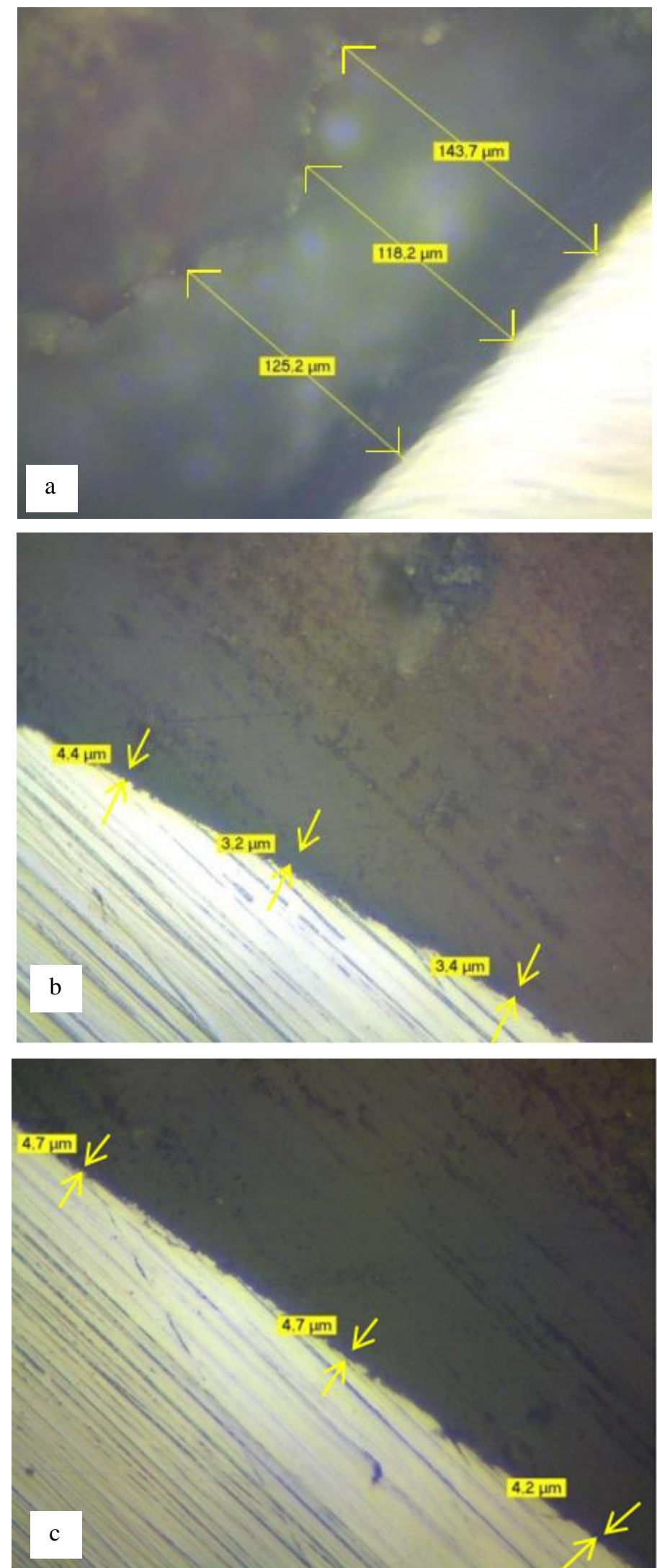

Figure 14: The micro photo of interface distance at zeolite ceramic matrix with SS316 fiber at sintering temperature of a. $800^{\circ} \mathrm{C}$. b. $850^{\circ} \mathrm{C}$. c. $900^{\circ} \mathrm{C}$

In Figure 14a it is explained that the average distance of the interface between SS316 fiber and zeolite ceramic matrix at the sintering temperature of $800^{\circ} \mathrm{C}$ were $143 \mu \mathrm{m}$, this distance is the biggest among the 
others. This shows that at the sintering temperature of $800^{\circ} \mathrm{C}$, the zeolite ceramic matrix can not gripped the SS316 fiber well, so the shear stress which was generated is relatively small. Whereas at the sintering temperature of $850^{\circ} \mathrm{C}$ and $900^{\circ} \mathrm{C}$ there is a shorter distance. The interface distance among them is slightly different, but the result of the pull-out test of the shear stress at the sintering temperature of $900^{\circ} \mathrm{C}$ is the smallest among others. The measurement of the distance gap can be done with a microscope and a software image raster as seen in Figure 15.

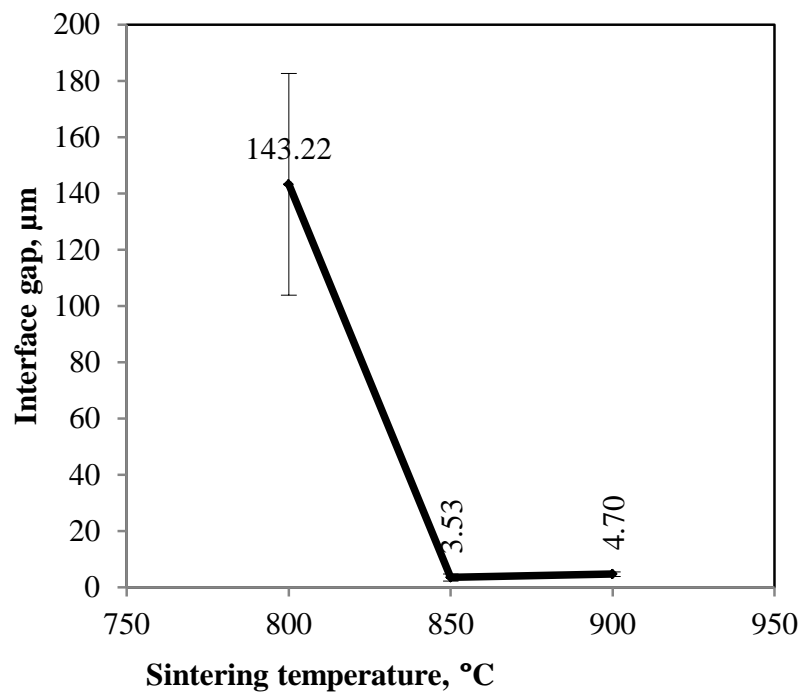

Figure 15: The sintering temperatures toward the zeolite ceramic matrix interface gap and fiber SS316.

Figure 15 shows the widest interface gap at the sintering temperature of $800^{\circ} \mathrm{C}$, because at that temperature there is only a small sintering shrinkage.

\section{DISCUSSION}

Figure 5 explains that the shear stress increases in the pull-out test on the sintering temperature of 800 to $850^{\circ} \mathrm{C}$, then down at the sintering temperature of $900^{\circ} \mathrm{C}$. The Pull-out force that they was obtained is $15-46$ $\mathrm{N}$, this result shows not much different from the findings of Cailleux [13], he was used stainless steel 310 fiber with a diameter of $2 \mathrm{~mm}$ and alumino silicate oxide matrix at firing temperatures of $980^{\circ} \mathrm{C}$. The higher the sintering temperature, the greater the ceramic shrinkage [4, 17] and also it should be able to grip the SS316 fiber stronger. In these results, it indicates that there is an increase in the interfacial shear stress at a sintering temperature of $800^{\circ} \mathrm{C}$ to $850^{\circ} \mathrm{C}$ While at the sintering temperature of $900^{\circ} \mathrm{C}$ it declined again. This is because there is a decrease in stainless steel elements. The decline force was suspected a influence not only mechanical strength, but also their the chemical changes in stainless steel.

The $\mathrm{Cr}$ decrease connected with research done by Pandey et al., where the $\mathrm{Cr}$ content is not detected because it was adsorbed slightly by the zeolite [18]. In the other hand, the Ni content is slightly increased associated with the increasing sintering temperature. The Ni content is obtained from the zeolite diffusion. The Fe content decrease is considered that Fe interact with the ceramics so that it changed into an easily cracked material. According to Cabrera et al. [19] Fe can be oxidized because of the zeolite content, where zeolite contains plenty of water and alkaline. This shows that chemical reactions occur in the Fe content, while the other element contents are not, because it is considered to be relatively fixed. Fe gained $\mathrm{O}$ from zeolite and had formed $(\mathrm{O}) \mathrm{Fe}$, where finally Fe got oxidized and formed $\mathrm{Fe}_{2} \mathrm{O}_{3}$ [20, 21, 22]. Kharisov et al. also mentioned, that $\mathrm{Fe}$ was treated in a furnace and implement alkali at a temperature below $1000^{\circ} \mathrm{C}$ which result in $\mathrm{Fe}_{2} \mathrm{O}_{3}$ [23]. To clarify the existing content in the layer between the crust stainless steel with ceramic zeolite, this research is trying to take the crust pulverized. The crust was tested XRD.

The Fe decreases as it reacts with the oxygen present in the zeolite content, The oxygen itself is obtained from $\mathrm{SiO}_{2}$ and $\mathrm{Al}_{2} \mathrm{O}_{3}$ which in the zeolite contained $66.9 \%$ and $11.43 \%$ respectively. The instability of zeolites at high temperatures causes the oxygen to react the Fe content in the stainless steels. As for the reaction that occurs like the reaction of Fenton's chemistry

$$
\mathrm{Fe}^{3+}+\mathrm{H}_{2} \mathrm{O}_{2} \rightarrow \mathrm{Fe}^{2+}+\mathrm{H}^{+}+\mathrm{HO}_{2}{ }^{*}
$$




$$
\mathrm{Fe}^{2+}+\mathrm{H}_{2} \mathrm{O}_{2} \rightarrow \mathrm{Fe}^{3+}+\mathrm{HO}^{-}+\mathrm{OH}^{*}
$$

The $\mathrm{Fe}$ reduction is the result of the natural acid weathering that can reduce of $\mathrm{Cr}$ levels. The reaction that occurs in $\mathrm{Cr}$ follows equation 3.

$$
2 \mathrm{Fe}+2 \mathrm{CrO}_{4}^{2-}+\mathrm{H}_{2} \mathrm{O}+4 \mathrm{H}^{+} \rightarrow 2 \mathrm{Fe}(\mathrm{OH})_{3}+\mathrm{Cr}_{2} \mathrm{O}_{3}
$$

The equation 3 gives an increase in $\mathrm{pH}$ due to the alkaline mixture of zeolites and the acidic properties of $\mathrm{Fe}$ weathering thus making them a thin layer between the zeolites and the stainless steels.

From the XRD test result the layer between stainless steel and zeolite ceramic are iron $(\mathrm{Fe})$, nickel iron $(\mathrm{FeNi})$, and chromium iron $(\mathrm{CrFe})$. This result is consistent with the results of atomic absorption spec test which indicating that $\mathrm{Fe}$ content was decreased. The $\mathrm{Ni}$ content is obtained from the zeolite while the $\mathrm{Cr}$ content is obtained from stainless steel and zeolite. The effect on the interface is being studied also with the existence of this crust layer also. This thin layer is expected to affect the interfacial tension between the SS316 fiber with zeolite ceramic matrix, which would resulting cracks on ceramics. These the cracks can also be seen in Figure 13f. The crust may occur because of the SS316 fiber expansion with zeolite ceramic matrix which did not match to each other or maybe because of the SS316 fiber reaction with zeolite ceramic matrix. The most striking reaction of this chemical reaction is the reduction of Fe in SS316 fiber which resulted in the zeolite ceramic matrix fragility. In this discussion synchronized between the interface gap on the surface of the zeolite and stainless steel.

This shows that at the sintering temperature of $800^{\circ} \mathrm{C}$, the zeolite ceramic matrix can not gripped the SS316 fiber well, so the shear stress which was generated is relatively small. Whereas at the sintering temperature of $850^{\circ} \mathrm{C}$ and $900^{\circ} \mathrm{C}$ there is a shorter distance. The interface distance among them is slightly different, but the result of the pull-out test of the shear stress at the sintering temperature of $900^{\circ} \mathrm{C}$ is the smallest among others. It means that when the SS316 was shrinking during the cooling process, the zeolite ceramic matrix do not shrink by following the SS316 shrinkage. According to Mascolo et al. [9] the zeolite which is heated below $700^{\circ} \mathrm{C}$ had a negative coefficient of expansion so as to make a wide distance interface of the zeolite ceramic matrix with fiber SS316. The graph in Figure 15 proves that at sintering temperatures of $850^{\circ} \mathrm{C}$ and $900^{\circ} \mathrm{C}$, the gap within the interface does not show any much different, it is only about $1 \mu \mathrm{m}$ wider at the sintering temperature of $900^{\circ} \mathrm{C}$. In some macro photos of zeolite ceramic matrix at the sintering temperature of $900^{\circ} \mathrm{C}$, there are some cracks around the holes (Figure 13f). The crack is cause of the weak stranglehold on the SS316 fiber which also makes the interfacial shear stress lower than the others. This cracking is caused by ceramics that can no longer withstand stainless steel expansion.

The results of this study still do not take into account the ratio of ceramic matrix with stainless steel fibers. For further research will be used to make composites by taking into account the ratio of ceramic matrix with stainless steel fibers.

\section{CONCLUSIONS}

The highest interfacial shear stress test result is in the sintering temperature of $850^{\circ} \mathrm{C}$. At this sintering temperature is the most synchronous between the zeolite ceramic matrix with SS316 fibers. Where it happened the strongest mechanical bond. However all of those elements are the cause of the weakness between zeolite ceramic matrix with SS316 fiber.

\section{ACKNOWLEDGMENTS}

The author would like to thank all those who helped on the implementation of this experiment, especially to Ministry of Research Technology and Higher Education of Indonesia.

\section{BIBLIOGRAPHY}

[1] EYDE, T. E. AND HOLMES, D. A., Zeolite, in book Industrial Minerals \& Rocks: Commodities, Markets, and Uses, editor Elzea, K. J., Trivedi, N. C., Barker, J. M., Krukowski, S. T., Society for Mining Metallurgy and Exploration Inc., Colorado, 2006.

[2] PAVELIC', K., HADZ`IJA, M. "Medical Applications of Zeolites", In: Handbook of Zeolite Scient, Marcel Dekker, Inc. 2003.

[3] BEDI, R. S., Anticorrosion and biocompatible zeolite based coating for tissue regeneration on metallic bioimplants, Degree Ph.D, Riverside, 2009.

[4] HRISTOV, P., YOLEVA, A., DJAMBAZOV, ST., et al., Preparation And Characterization Of Porous 
Ceramic Membranes For Micro-Filtration From Natural Zeolite, J. the University of Chemical Technology and Metallurgy, v.47, n. 4, pp.476-480, 2012.

[5] SAN, O., ABALI, S., HOSTEN, C., "Fabrication of Microporous Ceramics from Ceramic Powders of Quartz-Natural Zeolite Mixtures”, Ceramic International, v.29, pp. 927-931, 2003.

[6] HENCH, L., Bioceramics: From Concept to Clinic, Journal of the American Ceramic Society, v. 74, n. 7, pp. 1487-1510, 1991.

[7] SUH, H., "Recent Advance in Biomaterials”, Yonsei Medical Journal, v. 39, n. 2, pp. 87-96, 1998.

[8] CALLISTER, W. D., Fundamentals of Materials Science and Engineering 5 edition, John Wiley \& Sons, Inc, New York. 2001

[9] MASCOLO, M.C., DELL'AGLI, G., FERONE, C., et al., "Thermal crystallization of ion-exchanged zeolite A”, Journal of the European Ceramic Society 23, 1705-1713, 2003.

[10] ERDEM, E., KARAPINAR, N., DONAT, R., "The removal of heavy metal cation bay natural zeolites", Journal of Colloid and Interface Science, 280, pp. 309-314, 2004.

[11] GUILLAMENT, R., LOPITAUX, J., HANNOYER, B., et al., "Oxidation of Stainless Steel (AISI 304 and 316) at high Temperature. Influence on the Metallic Substratum”, Journal de Physique IV, v. 3, pp. 349$356,1993$.

[12] ATANDA, P., FATUDINU, A., OLUWE, O., "Sensitization Study of Normalized 316L Stainless Steel”, Journal of Mineral \& Materials Characterization \& Engineering, v. 9, n. 1, pp. 13-23, 2010.

[13] CAILLEUX, E., CUTARD, T. BERNHART, G., "Pull out of metallic fibers from a ceramic refractory matrix", Composite: Part A, v.33, 1461-1466, 2002.

[14] BAGBY, M., MARSHALL, S. J., MARSHALL, JR. G. W., "Metal ceramic compatibility: A review of the literature", The Journal of Prosthetic Dentistry, v. 63, n. 1, pp. 21-25, 1990.

[15] QIAN, S. AND LI, V. C., "Headed Anchor/ Engineered Cementitious Composites (ECC) Pull out Behavior", Journal of Advanced Concrete Technology, v. 9, n. 3, pp.339-351, 2011.

[16] HEARD, W.F., BASU, P.K., SLAWSON, T., et al., "Characterization and performance optimization of a cementitious composite for quasi-static and dynamic loads", Procedia Engineering, v. 10, pp. 3028-3033, 2011.

[17] RESPATI, S. M. B., SOENOKO, R., IRAWAN, Y. S., et al., "Effect of Low Temperature Sintering on the Porosity and Microstructure of Porous Zeolite Ceramic", Applied Mechanics and Materials, n.836, pp. 219-223, 2016

[18] PANDEY, P. K., SHARMA, S. K., SAMBI, S. S., "Kinetics and equilibrium study of chromium adsorption on zeolite NaX”, Int J. Environ Sci Tech, v. 7, n. 2, pp. 395-404, 2010.

[19] CABRERA, I. M., KAPTEIJN. F., MOULIJN, J. A., "Innovations yn the synthesis of Fe-(exchanged)zeolite", Catalysis Today, v. 110, pp. 255-265, 2005.

[20] YURANOV, I., BULUSHEV, D. A., RENKEN, A., et al., "Benzene hydroxylation over FeZSM-5 catalysts: which Fe sites are active?”, Journal of Catalysis, v.227, n.1, pp 138-147, 2004.

[21] YURANOV, I., RENKEN, A. KIWI-MINSKER, L."Zeolite/sintered metal fibers composites as effective structured catalysts", Applied Catalysis, v.281, n.1-2, pp 55-60, 2005.

[22] JIANG, S., ZHANG, H., YAN, Y., et al., "Stability and deactivation of Fe-ZSM-5 zeolite catalyst for catalytic wet peroxide oxidation of phenol in a membrane reactor", RSC Advances, v. 5, pp.41269-41277, 2015 .

[23] KHARISOV, B. I., DIAS, H. V. R., KHARISSOVA, O. V., et al., "Iron-containing nanomaterial's: synthesis, properties, and environmental applications”, RSC Advances, v.2, pp. 9325-9358, 2012. 